\title{
Gender differentials in the Use of Instructional Models in Enhancing Adolescents' Interest and Achievement in Voter Education Contents of Senior Secondary School Government Curriculum
}

\author{
Grace Ogechukwu Ugwonna ${ }^{1}$, Samuel Agozie Ezeudu ${ }^{1}$, Okechukwu Onyinye Nwaubani ${ }^{1}$, \\ Anthonia N. Utoh-Ofong ${ }^{2}$, Obiageli Calista Onyeanusi ${ }^{1}$, Patricia Nwamaka $\mathrm{Aroh}^{1}{ }^{1}$, Samuel Okechukwu Ome ${ }^{1}$, \\ Luke Chizoba Ezema ${ }^{1}$, Chidi Nathaniel Agbo ${ }^{3}$, Chijioke Chimaobi Offor ${ }^{1} \&$ Edith N. Nwokenna ${ }^{4}$ \\ ${ }^{1}$ Department of Social Science Education, University of Nigeria, Nsukka, Enugu, Nigeria \\ ${ }^{2}$ Quality Assurance Dept National Examinations Council (NECO), Minna, Niger State, Nigeria \\ ${ }^{3}$ Department of Curriculum and Instruction, Federal College of Education, Eha-Amufu, Enugu State, Nigeria \\ ${ }^{4}$ Department of Arts Education, University of Nigeria, Nsukka, Enugu, Nigeria \\ Correspondence: Dr. Anthonia. N Utoh-Ofong, Quality Assurance Dept National Examinations Council (NECO), \\ Minna, Niger State, Nigeria. E-mail: toniautoh@yahoo.com
}

Received: January 17, 2020 Accepted: April 27, 2020 Online Published: May 8, 2020

doi:10.5539/gjhs.v12n5p121 URL: https://doi.org/10.5539/gjhs.v12n5p121

\begin{abstract}
The study determined gender effect in the efficacy of group investigation and jurisprudential inquiry instructional models in enhancing adolescent students' interest and achievement in voter education related contents of senior secondary school Government curriculum. The study adopted quasi-experimental non-equivalent pre-test, post-test control group design. Sample for the study consisted of 165 SS II students drawn from senior secondary schools in Nsukka Local Government Area of Enugu state Nigeria. Multi-stage sampling technique was used to select the intact classes from each of the schools that were assigned to the two experimental groups. Data collected using Multiple Choice Government Achievement Test (MCGAT) and Government Interest Inventory (GII) were analyzed using mean and standard deviation for the research questions and ANCOVA for testing the hypothesis at $\mathrm{P}<0.05$ level of significance. The findings showed that both group investigation and jurisprudential inquiry models were effective in enhancing interest and achievement of male and female students in voter education related contents in senior secondary school Government curriculum. However, group investigation proved more efficacious. These findings were exhaustively discussed with recommendations on how to manage gender factor in using student-centred instructional models in enhancing students' interest and achievement.
\end{abstract}

Keywords: Voter education, gender, interest, academic achievement, adolescents, instructional model

\section{Introduction}

The persistent trend of low voter turnout in elections, particularly among youths in Nigeria between 1999 and 2015 has been a major concern in the political development of the country in recent times. The reason could be attributed to poor governance, electoral fraud and political violence (Chukwuemeka, Okoye, Egboh, \& Ewuim, 2012; Oni, 2014). This trend replicates in other countries where a significant increase in low turnout among youths has been established by studies (Blais \& Rubenson, 2013; Danielle \& Danielle, 2011). In retrospect, Resnick and Casale (2011) argued that older African citizens tended to vote more and easily expressed a higher degree of partisanship than their younger population. Several studies have attempted to ascertain the factors affecting youth turnout in elections as patrimonialism, cynicism (International Institute for Democracy and Electoral Ideas [IDEA], 2018), parental disposition to politics, peer ideology, lack of political and civic knowledge and lack of interest in formal politics (Journell, 2014; Torney-Purta \& Amadeo, 2003; Cohen \& Chaffe, 2012). Consequently, low turnout by youths affects the general turnout. As found by IDEA (1999), countries, where there were records of low turnout in their general elections had few youths that participated in those elections why countries that recorded high turnout equally showed high turnout among youths.

Low turnout rate may suggest that citizens are no longer interested in the electoral process. This indeed is worrisome despite the voter education by Electoral bodies and political parties in educating the citizens on the 
essence of voting in elections, although political parties in Nigeria rarely give enough political education. Thus Ibeanu (2014) remarked that declining turnout at elections could be attributed to inadequate voter education.

\subsection{Voter Education}

Voter education is a programme designed for information and material dissemination to inform voters about the rudiments of the voting process in an election and the entire electoral process (United Nations, 2007; Agyiri, 2012). It emphasizes on the functions of the voters and the impact of each vote on the outcome of the election results. The ultimate aim of voter education is to engage citizens with messages that will help achieve their cooperation in elections, increase voter turnout, reduce the number of invalid votes and ensure adherence to ethical considerations in voting (Jega, 2014). Thus, voter education provides citizens with the basic information required for the exercise of voting rights and expression of their political will. It could be transmitted through televised messages, radio, print media or social media.

In realization of the vital role of voter education to sustainable democracy, the Federal Ministry of Education [FME] in Nigeria (2007) streamlined voter education related contents into school subjects such as Government. As an academic field of study, Government is the study of individual behaviour, groups and organizations in society, especially as regards their relationship with the state power (Obianyo, 2002). The voter education related contents as stipulated in the senior secondary school Government are; election, suffrage, electoral systems, organization of elections and Electoral Commission. These contents are to complement the voter education programme. Buttressing the above, Ibeanu (2014) stated that voter education programme could be more potent when combined with a school programme. This is necessitated by the role of education in inculcating social norms and values in the citizens. Those values such as right voting behaviour, fair play, tolerance among others could be inculcated in the learners through voter education related contents for the development of democratic culture (Dag, Sozel, \& Sel, 2015). This position resonates with Kam and Palmer (2008) opinion that the most significant factor affecting students' political disposition is what they learn in school. Similarly, Journell (2011) stated that through interactions in school, students develop political skills and orientations that shape their political life. However, studies (Niemi \& Niemi, 2012) have noted with dismay that students' opinion on political participation are suppressed in formal classroom discussions. This trend persists in Nigeria classrooms where teachers do not engage students in interaction that could enhance critical thinking among students (Gilbert, 2014; Nyamwembe, Ondig, \& Kiio, 2013). To this end, scholars advocated the need for effective teaching of political contents (Dag, Sozel, \& Sel, 2015; Ogujawa \& Udoh, 2015; Journell, 2014) using student-centred instructional strategies that are interactive in nature.

\subsection{Instructional Strategies}

Theoretical postulation by Dewey (1938) emphasized the role of education in changing an individual's perception of politics. Dewey advocated that the core teaching is the arrangement of environments within which the students can interact and study how to learn. In line with Dewey's view, some scholars developed instructional models that could enhance students' acquisition of skills for democratic participation (Thelen, 1960; Oliver \& Shaver, 1966; Joyce \& Weil, 2000). Group investigation model is primarily designed for the development of skills for democratic participation through inter-personal social (group) skills (Joyce \& Weil, 2000; Siddiqui, 2013). This type of instruction constitutes four basic features which include investigation, interaction, interpretation and intrinsic motivation, compared with teacher-centred instruction, for internalization and enhanced knowledge (Lazarowitz, Hertz-lazarowitz, Khalil, \& Ron, 2013). Group investigation has six steps to be followed during instruction. They are; grouping, planning, investigating, organizing, presentation and evaluation. Grouping involves categorization of questions raised and grouping of students. Planning involves students dividing tasks among themselves and then investigating the issues raised using relevant materials. The next is to organize their different ideas and plan on how to present their findings, followed by a presentation, after which the students evaluate themselves.

Jurisprudential inquiry model as developed by Oliver and Shaver (1966) emphasizes problem-solving approach through the jurisprudential frame of reference. It enhances knowledge connection to the society and develops in students values and attitude through discussions, debates, and arguments over controversial issues for efficient policy making among the citizens (Nwafor, 2014; Damanik, Degeng, Setyosari, \& Dasna, 2016; Toyosi \& Aminat, 2018). Jurisprudential inquiry model involves the following steps; orientation to the case, identifying the issues, taking positions, exploring the stance, refining the positions and testing factual assumptions. In the first step, the teacher arranges the students in groups after introducing the topic of the lesson, after which the students gather and analyze facts in groups. The students get back together as an intact class to share information among different groups and then prepare to debate on the issue raised. These models have been understudied to test their efficacy in terms of ascertaining the extent their postulations are true (or not) with reference to students' interest and academic 
achievement in political contents among in-school adolescents.

Ideally, political instruction ought to expose students to politics and current political events in a manner that arouses students' interests and makes politics appear important to them (Journell, 2011). However, there seems to be a decline in the interest of students in the study of Government which could affect their academic achievement especially in voter education related contents which are capable of promoting active political participation among in-school adolescents at the senior secondary school level. Studies have attributed students' disengagement in politics to lack of interest which makes them not to attach value to active political participation (Campbell, 2005; Hibbing \&Theiss-Morse, 2002; Lopez, Kirby, \& Sagoff ,2005). This suggests that the willingness of the young ones to actively participate in electoral process could be influenced by the method of instruction and proper awareness creation. Niemi and Niemi (2012) observed from their study that student opinions on political participation were frequently suppressed in formal classroom interactions. This may have resulted to a decline in voting among the in-school adolescents of voting age (Martin \& Chiodo, 2005; Torney-Purta, Barber, \& Wilkenfeld, 2007) be it male or female adolescents.

\subsection{Gender}

In Nigeria, political participation is gender centred as a result of socio-economic factors such as patriarchal system, cultural bias, societal stereotype, violence, financial income among others (Awofeso \& Odeyemi, 2014; Akpan, 2015; Luka, 2011). Consequently, Nigeria has been recording low participation of women in both elective and appointive positions. Thus, the $35 \%$ affirmative action is yet to be fully implemented. This could have implications for female adolescents studying politically related contents such as voter education. Perhaps, female students could be deterred considering the fact that there is a vast proportion of male to female in politics as may be stipulated in the Government textbooks. Furthermore, it could also make them score lower in their academic achievement than their male counterparts, although there is no consensus agreement on the extent gender influences students' academic achievement.

While studies (such as Dania, 2014; Clifford \& Akpochafo, 2015; Owoduni, 2013) found that gender does not influence students' achievement, in contrast, other studies (such as Amedu, 2015; Nnamani \& Oyibe, 2016) found a significant effect of gender on students' academic achievement. Further studies found men to have more interest in politics than their women counterparts (Henn, Weinstein, \& Forest, 2005). Also, Amoateng, Kalule-Sabiti and Heaton (2014) show that, in general, women are two thirds as likely to turn out as men, with the gender gap in turnout varying extensively across African countries through time. Thus, the crux of this study was to determine the extent students' gender could influence their interest and academic achievement in voter education related contents of senior secondary school Government curriculum as a result of their exposure to group investigation and jurisprudential inquiry models.

To carry out the study, two research questions and two null hypotheses guided the study.

\subsection{Research Questions}

The following research questions were formulated to guide the study

1. What is the influence of gender on the mean interest scores of students taught voter education related contents in senior secondary school Government using group investigation model and jurisprudential inquiry model?

2. What is the influence of gender on the mean achievement scores of students taught voter education related contents in senior secondary school Government using group investigation model and jurisprudential inquiry model?

\subsection{Hypotheses}

$\mathbf{H o}_{1}$ : There is no significant difference in the mean interest scores of male and female students in voter education related contents of Senior Secondary School Government using group investigation model and jurisprudential inquiry model.

$\mathrm{Ho}_{2}$ : There is no significant difference in the mean achievement scores of male and female students in voter education related contents of Senior Secondary School Government using group investigation model and jurisprudential inquiry model.

\section{Materials and Methods}

\subsection{Study Design and Study Population}

This study adopted a non-equivalent control group quasi-experiment design. It was carried out in public secondary 
schools in Enugu State, Nigeria that offer voter education related contents in Government. The sample size for this study consisted of 165 SS11 students in four intact classes drawn from four (4) schools in Nsukka LGA out of which 48 are males while 117 are females. Multi-stage sampling technique was used for the sampling. The stages of the sampling were as follows;. Firstly; stratified random sampling was used to select co-educational schools from 30 public secondary schools in Nsukka LGA. Four co-educational secondary schools were drawn from the 23 co-educational public secondary schools through simple random sampling. Secondly, purposive sampling technique was used to select SS11 students. Purposive sampling technique was used because voter education related contents are in SS11 Government scheme of work. Thirdly, one intact class each from the four co-educational public secondary schools from 23 co-educational public secondary schools in Nsukka LGA was drawn randomly, making a total of four intact classes. Two intact classes drawn from two schools received GIM treatment and the other 2 intact classes received JIM treatment. The intact classes were assigned to experimental groups randomly. Thus, 87 students were assigned to Group Investigation while 78 students were assigned to Jurisprudential Inquiry group. There were 27 male and 60 female students in Group Investigation model group while 21 males and 57 females were assigned to Jurisprudential Inquiry group.

Two lesson plans were developed by the researchers for the experiment based on the features of each of the models. Regular teachers of Government conducted the experiment. However, the researchers monitored the experiment for effective implementation of the steps involved in the instructional models.

\subsection{Instrument for Data Collection}

Two instruments developed by the researchers were used for data collection. They were titled Multiple Choice Government Achievement Test (MCGAT) and Government Interest Inventory (GII). MCGAT is a structured 50 multiple choice items with four options A-D. The MCGAT items were generated based on voter education related contents found in the senior secondary school Government curriculum, in which only one option was the correct answer. Specifically, MCGAT items were drawn from topics such as election, suffrage, Electoral system, features of free and fair election and electoral commission. MCGAT was specifically designed to measure students' understanding and academic achievement in Voter education related contents of senior secondary school Government at all levels of the cognitive domain of Bloom's Taxonomy.

The second instrument was a structured interest inventory titled Government Interest Inventory (GII). The instrument (GII) is divided into two main sections namely section A and B. Section A was used to elicit information on students demographic data while section B contained information on students' level of interest in learning voter related issues in senior secondary school Government. The items are on a four point rating scale of Strongly Agree (SA), Agree (A), Disagree (D), Strongly Disagree (SD) with weighting scale of 4, 3, 2, and 1 respectively. To establish the validity of the research instruments, MCGAT and GII were subjected to face and content validation. To determine the reliability of the instruments, MCGAT and GII were administered to students as pre test in a school that was not used for the study. Data obtained through the administration of achievement test were analysed using Kudder-Richardson formular (KR -20) test statistics. The reason for the use of KR-20 was because items of MCGAT were dichotomously scored and were not at the same level of difficulty. Reliability index of 0.79 was established. To determine the temporal stability of the instrument, a test retest was used by re-administering the MCGAT instrument to the same group of students after a period of two weeks of the first administration. The two sets of scores obtained in the two occasions were correlated using Pearson Product Moment and a correlation coefficient of 0.89 was established which shows a high correlation of the two scores.

The reliability index for GII was calculated using Cronbach Alpha. A reliability coefficient of 0.81 was established. Cronbach Alpha was used in calculating the reliability for GII because every item attracts a score and within a scale. The MCGAT and GII had coefficient of 0.89 and 0.81 respectively. The same instruments were re-administered to the students as post test. Data collected were analyzed using SPSS version 20. Mean and standard deviation were used for measures of central tendency while the level of significance of $\mathrm{P}<0.05$ was adopted. A hypothesis was not rejected if the probability value is greater than 0.05 level of significance and vice versa.

\section{Results}

\subsection{Research Question One}

What is the influence of gender on mean interest scores of students taught voter education related contents? 
Table 1. Mean interest scores of male and female students in voter education related contents in Government subject

\begin{tabular}{llllllll}
\hline \multirow{2}{*}{ Treatment } & $\mathrm{N}$ & \multicolumn{2}{l}{ Pretest } & & \multicolumn{2}{l}{ Posttest } & Mean Gain \\
& & Mean & SD & & Mean & SD & 9.08 \\
Male & 48 & 82.08 & 13.84 & & 91.16 & 8.90 & 6.21 \\
\hline
\end{tabular}

The results in Table 1 show that the male students taught voter education related contents had the pre-test and post-test mean interest scores of 82.08 and 91.16 with standard deviation of 13.84 and 8.90 respectively. Meanwhile, the female students taught the same content had the pre-test and post-test mean interest scores of 82.38 and 89.19 with standard deviation of 14.53 and 7.87 respectively. However, mean gain scores of 9.08 for male students and 6.21 for female students imply that male students showed greater interest than their female counterparts in voter education related contents.

\subsection{Research Question Two}

What is the influence of gender on the mean achievement scores of students in voter education related contents?

Table 2. Mean and Standard Deviation of achievement scores of male and female students in voter education related contents

\begin{tabular}{llllllll}
\hline \multirow{2}{*}{ Treatment } & $\mathrm{N}$ & \multicolumn{2}{l}{ Pretest } & & \multicolumn{2}{l}{ Posttest } & Mean Gain \\
\cline { 3 - 4 } & & Mean & SD & & Mean & SD & 19.00 \\
Male & 48 & 15.83 & 5.87 & & 34.83 & 4.00 & 17.77 \\
Female & 117 & 16.28 & 5.48 & & 34.05 & 4.12 & 12 \\
\hline
\end{tabular}

Table 2 indicates the mean achievement scores of male and female students in voter education related contents. The analysis shows that the male students had post-test mean achievement score of 34.83 with a standard deviation of 4.00 while their female counterparts had post-test mean achievement score of 34.05 with a standard deviation of 4.12. However, mean gain scores of 19.00 and 17.77 for the male and female students respectively may have indicated that male students had slightly higher mean achievement score than their female counterparts.

$\mathbf{H O}_{1}$ : There is no significant difference in the mean interest scores of male and female students in voter education related contents of Government subject.

Table 3. ANCOVA for the difference in the mean interest scores of male and female students in voter education related contents of Government subject

\begin{tabular}{llllllc}
\hline Source & $\begin{array}{c}\text { Type III Sum of } \\
\text { Squares }\end{array}$ & Df & Mean Square & F & Sig. & $\begin{array}{c}\text { Partial Eta } \\
\text { Squared }\end{array}$ \\
\hline Corrected Model & $248.107^{\mathrm{a}}$ & 2 & 124.054 & 1.860 & .159 & .022 \\
Intercept & 34819.485 & 1 & 34819.485 & 522.140 & .000 & .763 \\
Preinterest & 116.004 & 1 & 116.004 & 1.740 & .189 & .011 \\
Gender & 134.479 & 1 & 134.479 & 2.017 & & .012 \\
Error & 10803.141 & 162 & 66.686 & & & \\
Total & 1340720.000 & 165 & & & & \\
Corrected Total & 11051.248 & 164 & & & & \\
\hline
\end{tabular}

The result in Table 3 shows an F-ratio of 2.017 and a probability value of 0.158 for the difference in the mean interest scores of male and female students in voter education related contents. Since the probability value is higher than 0.05 level of significance, the null hypothesis was not rejected but retained meaning that there is no significant 
difference in the mean interest scores of male and female students in voter education related contents.

$\mathbf{H O}_{2}$ : There is no significant difference in the mean achievement scores of male and female students in voter education related contents of Government subject.

Table 4. ANCOVA of the difference in mean achievement scores of male and female students in voter education related contents of Government subject

\begin{tabular}{lllllll}
\hline Source & Type III Sum of Squares & df & Mean Square & F & Sig. & Partial Eta Squared \\
\hline Corrected Model & $2340.255^{\mathrm{a}}$ & 2 & 1170.128 & 68.007 & .000 & .456 \\
Intercept & 3796.338 & 1 & 3796.338 & 220.642 & .000 & .577 \\
Pretest & 2319.891 & 1 & 2319.891 & 134.831 & .000 & .454 \\
Gender & 47.834 & 1 & 47.834 & 2.780 & .097 & .017 \\
Error & 2787.357 & 162 & 17.206 & & & \\
Total & 199077.000 & 165 & & & & \\
Corrected Total & 5127.612 & 164 & & & & \\
\hline
\end{tabular}

Table 4reveals that the calculated value of F (2.780) for the influence of gender on students' achievement in voter education related contents had an associated probability value of 0.097 . Since the probability value of 0.097 is greater than the 0.05 level of significance, the null hypothesis was not rejected but retained meaning that there is no significant difference in the mean achievement score of male and female students in voter education related contents. Hence, it appears that the two models are gender-sensitive and not bias. This implies that the two models are suitable for teaching both male and female students.

\section{Discussion}

The findings of this study revealed that male students showed greater interest in voter education related contents than their female counterparts. However, further analysis revealed that there is no significant difference in the mean interest scores of male and female students taught using group investigation model and those taught using jurisprudential inquiry model. The differences in the mean interest scores may have been induced by the fact that women seem not to show interest in politics as much as the men as a result of some associated factors ranging from cultural belief, intimidation among others. These and more factors may have affected the impression of the female students towards voter education related contents which made them not to have much interest in voter education related contents as their male counterparts. However, since the difference is not statistically significant, it suggests that both models captivated both male and female students' interest in voter education related contents of senior secondary school Government.

This implies that if properly taught, both men and women could have the same interest in participating in politics. This, therefore, shows that both group investigation model and jurisprudential inquiry model are effective instructional models that enhance students' interest in voter education related contents regardless of gender. This finding suggests that female adolescents have an interest in studying political contents as their male counterparts. The implication of this finding shows that women inability to participate actively in politics is not as a result of the gender factor. This finding is in line with the findings of Godpower-Echie and Ihenko (2017), Ajayi, AgamberandAngura (2017), Kehinde and Alebiosu (2006) which found that gender is a determinant of students' interest but statistically not significant.

The findings of the study also indicated that male students scored higher than the female students in voter education related contents when taught using group investigation model and jurisprudential inquiry model, although not statistically significant. This finding suggests that both models enabled the students to corroborate and interact among their groups, which made them had meaningful learning. These findings are in line with the findings of Oche (2012) which no significant difference in mean achievement between boys and girls and Godpower-Echie and Ihenko (2017); Attah and Ita (2017) which found that male students scored higher than their female counterparts. However, the finding is in contrast with the findings of Nnamani and Oyibe (2016) which found that mean achievement score of female secondary school students was higher than the mean achievement scores of male students. 


\section{Conclusion}

This study was motivated by the incidence of voter apathy particularly among youth despite the voter education contents streamlined in the school curriculum and the inability of teachers to employ student-centred instructional strategies. The ultimate aim was to determine whether the male and female students' interest and achievement in studying voter education related contents of senior secondary school Government curriculum could be enhanced as a result of exposure to group investigation and jurisprudential inquiry models. Findings showed that students' interest and achievement enhanced with male students having slightly higher interest and achievement scores. However, the difference was not statistically significant.

These findings imply that if school subjects such as voter education related contents are taught using effective student-centred instructional strategies, the male and female students are likely to acquire lifelong learning, capable of making them take rational decisions in the society. Secondly, if students are appropriately engaged in voter education contents using student-centred instructional strategies; adolescents are likely to develop interest in participating in the electoral process, thereby minimizing to a great extent the incidence of voter apathy in Nigeria. The study, therefore, recommends that voter education clubs should be introduced in schools to further intimate adolescents on the need for effective participation in electoral processes. Furthermore, teachers are encouraged to employ student-centred instructional strategies in teaching school contents. This study contributes to the field of electoral participation and instructional strategies. The adolescents being the future adults ought to possess the skills needed to be able to sustain the principles of democracy. They can learn such skills through politically sensitive school contents, using student-centred instructional strategies.

\section{Acknowledgements}

We appreciate the teachers and schools that participated in the study. We particularly acknowledge the school administrators that granted permission to the researchers to carry out the research in their schools. The researchers equally appreciate the data analyst for analyzing the data. This research was fully sponsored by the researchers.

\section{Competing Interests Statement}

The authors declare that there are no competing or potential conflicts of interest.

\section{References}

Ajayi, V. O., Agamber, T., \& Angura, T. (2017). Effect of gender on students' interest in standard mixture separation techniques using ethnochemistry teaching approach. Sky Journal of Educational Research, 5(5), 27-33. https://papers.ssrn.com/sol3/papers.cfm?abstract_id $=3066324$

Agyiri, L. (2012). Assessment of voter education on electoral processes in the new Juaben municipality (an unpublished thesis).Institute of Distance Learning, Kwame Nkrumah University of Science and Technology. Retrieved from http://ir.knust.edu.gh/bitstream/123456789/4816/1/Lydia\%20Agyiri\%20\%28PG\%204083110\%29.pdf

Akpan, N. E. (2015). Men Without Women: An Analysis of the 2015 General Elections in Nigeria. Wukari: Political Science Dept., Federal University.

Amedu, O. I. (2015). The effect of gender on the achievement of students in biology using the jigsaw method.Journal of Education and Practice, 6(17), 176. Retrieved from www.iiste.org

Amoateng, A.Y., Kalule-Sabiti, I., \& Heaton, T. B. (2014). Gender and changing patterns of political participation in sub-Saharan Africa: evidence from five waves of the Afrobarometer surveys. Gender and Behaviour, 12(3), 5897-5910. Retrieved from https://hdl.handle.net/10520/EJC154466Google Scholar

Attah, R. F., \& Ita, P. M. (2017). Gender as predictor of academic achievement in English among senior secondary school two students in Calabar metropolis, Cross River state. Global Journal of Educational Research, (16), 149-153. https://doi.org/10.4314/gjedr.v16i2.9

Awofeso, O., \& Odeyemi, T. I. (2014). Gender and Political Participation in Nigeria: A Cultural Perspective. Journal Research in Peace, Gender and Development, 4(6). https://doi.org/10.14303/jrpgd.2014.023

Blais, A., \& Rubenson, D. (2013). The source of turnout decline: new values or new contexts? Comparative Political Studies, 46(1), 95-117. https://doi.org/10.1177/0010414012453032

Campbell, D. E. (2005b). Vote early, vote often: The role of schools in creating civic norms. Education Next, 5(3), 63-69.

Chukwuemeka, E. E. O., Okoye, J. C., Egboh, E. A., \& Ewuim, N. (2012). Obstacles to Nigeria Political 
Development - A Critical Evaluation. Journal of Public Administration and Governance, 2(2). https://doi.org/10.5296/jpag.v2i2.1987

Clifford, O. E., \& Akpochafo, W. P. (2015). Gender difference among social studies teachers' competences in the use of the inquiry method in South-South Nigeria. Journal of Education and Practice, 6(23), 48. Retrieved from www.soeagra.com/ijert/ijert.htm.

Cohen, A. K., \& Chaffe, B. W. (2012). The relationship between adolescents' civic knowledge, civic attitude, and civic behavior and their self-reported future likelihood of voting. EducCitizshSoc Justice, 8(1), 43-50. https://doi.org/10.1177/1746197912456339

Dag, N., Sozer, M. A., \& Sel, B. (2015). Political education in school. Educational Research and Reviews, 10(14), 1881-1887. https://doi.org/10.5897/ERR2015.2330

Damanik, H., Nyoman, I. S., Setyosari, P., \& Dasna, W. (2016). The learning of civics education based on contextual teaching and learning (CTL). Retrieved from pasca.um.ac.id > conferences > index.php >

Danielle, R., \& Daniela, C. (2011). The political participation of Africa's youth: turnout, partisanship and protest. Retrieved from https://www.files.ethz.ch/isn/134548/AfropaperNo136.pdf

Dania, P. O. (2014). Effect of gender on students' academic achievement in secondary school social studies. Journal of Education and Practice, 5(21), 78-91.

Dewey, J. (1938). Experience and education. New York: Macmillan

Federal Ministry of Education. (2007). Senior secondary school government curriculum. Abuja: NERDC.

Gilbert, L. D. (2014). Interrogating the fundamental challenges militating against the teaching and learning of government in Nigerian senior secondary schools. European Scientific Journal, 10(16), 225.

Godpower-Echie, G., \& Ihenko, S. (2017). Influence of Gender on Interest and Academic Achievement of Students in Integrated Science in ObioAkpor Local Government Area of Rivers State. European Scientific Journal, 13(10), 1857-7881. https://doi.org/10.19044/esj.2017.v13n10p272

Henn, M., Weinstein, M., \& Forest, S. (2005). Uninterested Youth? Young People's Attitudes towards Party Politics in Britain. https://doi.org/10.1111/j.1467-9248.2005.00544.x

Ibeanu, O. (2014). Introduction. In O. Ibeanu \& N. Orji (Eds), Approaches to civic and voter education: Nigeria's experience in comparative perspective (pp.9-27). Retrieved from https://www.researchgate.net/publication/271587770

International Democracy and Electoral Assistance. (2018). Voter turnout by election type: presidential. Retrieved from https://www.idea.int/data-tools/country-view/231/40

International Democracy and Electoral Assistance. (2018). Youth Participation in Political Processes Second Annual Summer School for Young Leaders from African Political Parties: Kigali, Rwanda, 6-8 June 2018. http://www.idea.int

International Democracy and Electoral Assistance. (1999). Youth voter participation:Involving today's young in tomorrow's democracy. Retrieved from https://www.idea.int/sites/default/files/publications/youth-voter-participation.PDF

Jega, A. (2014). Foreword. In O. Ibeanu \& N. Orji (Eds), Approaches to civic and voter education: Nigeria's experience in comparative perspective.

Journell, W. (2011a). Teaching politics in secondary education: Analyzing instructional methods from the 2008 Presidential Election. The Social Studies, 102(6), 231-241. https://doi.org/10.1080/00377996.2011.558939

Journell, W. (2011b). Learning to think politically: toward more complete disciplinary knowledge in civics and government courses. $\mathrm{http}: / /$ libres.uncg.edu/ir/uncg/listing. aspx? $\mathrm{id}=17807$

Journell, W. (2014). Teaching politics in the U.S. history classroom. The History Teacher, 48(1), 55-69. Retrieved from https://www.jstor.org > stable

Joyce, B.,\& Weil, M. (2000a). Models of teaching. Boston: Allyn and Bacon

Kam, C. D.,\& Palmer, C. L. (2008). Reconsidering the effect of education on political participation. Journal of Politics, 70(3), 612-631. https://doi.org/10.1017/S0022381608080651

Kehinde, A. A. (2006). Gender and students' interests in organic chemistry topics at the senior secondary level. Gender and Behaviour, 4(1), 522-533. https://doi.org/10.4314/gab.v4i1.23343 
Lazarowitz, R., Hertz-lazarowitz, R., Khalil, M., \& Ron, S. (2013). Designing cooperative learning in the science classroom: integrating the peer tutoring small investigation group (PTSIG) within the model of the six mirrors of the classroom model. Retrieved from https://files.eric.ed.gov/fulltext/ed567161.pdf

Luka, C. (2011). Women and Political Participation in Nigeria: The Imperative of Empowerment. Journal of Social Sciences and Public Policy, (3). Online: www.cenresin.org.

Martin, L. A., \& Chiodo, J. J. (2007). Good Citizenship: what Students in Rural Schools Have to Say about It. Theory and Research in Social Education, 35(1), 112-134. https://doi.org/10.1080/00933104.2007.10473328

Nwafor, C. (2014). Use of jurisprudential innovative approach in teaching basic science: an alternative to lecture method. International Researcher, 3(1), 63-67. Retrieved from https://www.researchgate.net/publication/281178754_use_of_jurisprudential_innovative_approach_in_teac hing_basic_science_an_alternative_to_lecture_method

Oche, E. S. (2012). Assessing the relative effectiveness of three teaching methods in the measurement of student' achievement in mathematics. Journal of Emerging Trends in Educational Research and Policy Studies (JETERAPS), 3(4), 479-486.

Niemi, N. S., \& Niemi, R. G. (2012). Partisanship, participation, and political trust as taught (or not) in high school history and government classes. Theory and Research in Social Education, 35(1), 32-61. https://doi.org/10.1080/00933104.2007.10473325

Nnamani, S. C., \& Oyibe, O. A. (2016). Gender and academic achievement of secondary school students in social studies in Abakaliki urban of Ebonyi state. British Journal of Education, 4(8), 72-83.

Nyamwembe, E. O.,Ondigi, S., \& Kiio, M. (2013). Attitudes of students toward studying history and government in some selected secondary schools in Mosocho Division, Kisii County.Kenya. Journal of Education and Practice, 4(11), 17. Retrieved from www.iiste.org

Obianyo, N. (2002). Government and its classifications.In P.N. Chinedu (Ed), Introduction to political science. Enugu: Academic pre

Ogujawa, A. I., \& Udoh, A. P. (2015). Strategies for improving the teaching and learning of government as a core-subject in senior secondary schools. International Journal of Educational Planning \& Administration, 5(1), 51-61. Retrieved from http://www.ripublication.com

Oliver, D.W., \& Shaver, J. (1966). Teaching pupil issue in the High School. Bostonma: Houghtonmiffin

Oni, E. O. (2014). The challenges of democratic consolidation in Nigeria, 1999-2007 international. Journal of Politics and Good Governance, 5(5.1)

Owodunni, A. S., \& Ogundola, I. P. (2013). Gender differences in the achievement and retention of Nigeria students exposed to concept in electronic works trade through reflective inquiry instructional technique. British Journal of Education, Society \& Behavioural Science, 3(4), 589-599, 2013. https://doi.org/10.9734/BJESBS/2013/4026

Resnick, D., \& Casale, D. (2011). The political participation of Africa's youth: Turnout, partisanship, and protest, 56. Working paper//World Institute for Development Economics Research.

Siddiqui, M. H. (2013). Group investigation model of teaching: enhancing learning level. Indian Journal of Research, 3 .

Thelen, H. (1960).Education and Human Quest. New York: Harper \& Row Publishers Inc.

Torney-Purta, J. (2002). A school's role in developing civic engagement: a study of adolescents in twenty-eight countries. Applied Developmental Science, 6(4), 203-212.https://doi.org/10.1207/S1532480XADS0604_7

Toyosi, M. S., \& Aminat, A. (2018). Effects of jurisprudential inquiry model of instruction on performance and retention on ecological concepts among secondary ii students in Nigeria. International Advanced Journal of Teaching \& Learning. Retrieved from https://www.zeetarz.com/iajtl/wp-content/uploads/2018/09/Effects-of-Jurisprudential-Inquiry-Model-of-Inst ruction-on-Performance-and-Retention-on-Ecological-Concepts-among-Secondary-II-Students-in-Nigeria.p $\mathrm{df}$

United Nations. (2007). Voter and civic education. Retrieved fromhttps://www.un.org/womenwatch/osagi/wps/publication/ 


\section{Appendix}

\section{Appendix A}

Multiple Choice Government Achievement Test (Mcgat) For Senior Secondary School II

\section{PERSONAL DATA}

You are requested to give appropriate response to the questions.

Age:

Class:

School:

\section{INSTRUCTION:}

Time: 50mins

Circle the correct answers by choosing any of the options A, B, C, and D as considered most appropriate by you. The questions are in four options.

1. Which of the following is an example of a general election?
(A) By-election
(B) Presidential election
(C) local election
(D) student union election

2. Election serves one of the following purposes;
(A) allow people to participate in choosing their leaders
(B) Provide social amenities for the electorates
(C) give political education to the rich
(D) Allow the counting of votes in public

3. What makes universal adult suffrage popular?
(A) equal political representation
(B) greater political participation
(C) multi-party system
(D) equal performance of all political system

4. Democratic electoral system is promoted by the following factors except;
(A) Political consciousness
(B) periodic election
(C) up-to-date electoral register
(D) Popularity of the governor

5. A factor that could make elections to be free and fair is the;
(A) existence of dependent electoral commission
(B) adoption of a flexible constitution
(C) opportunity for people to vote twice
(D) registration of eligible voters

6. Supervision of elections in West African countries is carried out by which boby? 

(A) ombudsman
(B) electoral commission
(C) election observers
(D) constituent assembly

7. All these are the problems of an electoral commission in West Africa except?
(A) Electoral malpractices
(B) inadequate personnel
(C) inadequate funds
(D) All of the above

8. A citizen's obligation is one of the following;
(A) Arresting offenders
(B) Voting at elections
(C) Prosecuting offenders
(D) Adjudicating cases.

9. Universal Adult suffrage is adopted by countries for the following reasons Except;
(A) It is democratic
(B) Interest of the people is protected
(C) masses participate
(D) It encourages rigging

10. The geographical units into which a country is divided for the purpose of election are called;
(A) States
(B) Constituencies
(C) Following areas
(D) Country Councils.

11. One of the following is the reason for conducting elections;
(A) to provide permanent employment for the people
(B) to make the people choose their leaders
(C) to know the number of people in a country
(D) to know the social amenities in the community

12. Another word for suffrage is;
(A) Franchise
(B) Plebiscite
(C) public opinion
(D) Electoral college

13. For an election to be fair and free, the Federal Commission Must be;
(A) ready to manipulate result
(B) ready to reject criticisms
(C) headed by a minister in the executive
(D) independent of other institutions of government

14. Which of the following categories of people can vote in periodic elections?
(A) minor
(B) Aliens 

(C) lunatics
(D) citizens

15. A 'Yes' or 'No' vote on a specific political issue in a country is called;
(A) referendum
(B) public opinion
(C) gerrymanding
(D) suffrage

16. The electoral system in which the winner should have more than all the votes of all other contestants put together is;
(A) simple majority system
(B) second ballot system
(C) referendum
(D) absolute majority system.

17. The following are the aims of election Except that;
(A) a group sticks on to power
(B) There is accountability of the leaders
(C) there is a smooth change of government
(D) The people determine who rules

18. The meaning of Franchise is to;
(A) manipulate election results
(B) Conduct election
(C) enforce electoral laws
(D) vote and be voted for

19. In limited franchise, restriction on voting can be based on;
(A) height
(B) property
(C) Strength
(D) exposure

20. The limitation of universal adult suffrage is;
(A) wealth
(B) Tribe
(C) sex
(D) none of the above

21. One of the functions performed by the electoral commission is;
(A) Distribution of party membership cards
(B) presentation of parties manifestoes
(C) creation of polling units
(D) conducting of oath of office for elected president.

22. The following electoral officers are found in a pooling booth Except
(A) Presiding officer
(B) Orderly
(C) Flag bearer 
(D) Pooling Clerk

23. A major advantage of secret ballot system of voting is that;
(A) it is faster than other system
(B) it ensures the anonymity of the voter
(C) it extends the franchise to all colts
(D) nobody can be prevented from voting

24. The 'first-past-the-post system of voting is also called
(A) second ballot system
(B) proportional representation
(C) second majority system
(D) alternative vote system

25. Which of the following is not a form of proportional representation?
(A) Alternative vote
(B) Second Ballot
(C) List system
(D) Plurality system

26. The process by which voters may remove a public officer before the end of his term of office is called;
(A) gerrymandering
(B) recall
(C) by election
(D) referendum

27. The term winner-takes-all can be associated with;
(A) Second ballot system
(B) Representative government
(C) First-past-the-post system
(D) Proportional representation

28. The process of depriving persons of the right of voting is called;
(A) enfranchisement
(B) disqualification dismissal
(C) prohibition
(D) disenfranchisement

29. An election where no absolute majority is obtained, the most viable option is the;
(A) Second ballot withdrawal
(B) Bye-election
(C) Second ballot
(D) Proportional representation

30. All these are not method of election except;
(A) Simple majority
(B) Proportional representation
(C) Absolute majority
(D) plurality system

31. A popular form of proportional representation is 

(A) Single transferable vote
(B) Communal Representation
(C) The alternative
(D) Electoral college

32. Any type of restricted franchise is a violation of the principle of;
(A) Constitutionalism
(B) Sovereignty
(C) Political equality
(D) Popular election

33. The process by which people vote to elect their representatives is called;
(A) Disenfranchisement
(B) Electoral system
(C) Franchise
(D) Electoral college

34. The electoral officer responsible for announcing of election results is the;
(A) Political officer
(B) Resident electoral commission
(C) Supervisory presiding officer
(D) Returning officer

35. To make elections hitch-free and fair, the electoral commission must be;
(A) able to punish electoral offenders
(B) given a spacious office accommodation
(C) ready to help the government
(D) independent of the executive.

36. One of these is not a feature of free and fair election;
(A) Registration of voters
(B) Issuance of voters card
(C) Lobbying of voters
(D) Display of voters register

37. The body responsible for the conduct of election in a country is called;
(A) Electoral committee
(B) Electoral ward
(C) Electoral party
(D) Electoral Commission

38. An election held when none of the candidates wins the election by absolute majority in a general election is known as
(A) Run-off Election
(B) Second Election
(C) Plebiscite
(D) Election rigging

39. A system in which a candidate with the highest number of votes is declared a winner in an election is called (A) Absolute system 

(B) Proportional representation
(C) Second ballot
(D) Simple majority

40. All these are not the meaning of free and fair election Except
(A) rigging of election
(B) Elections conducted following election rules
(C) Snatching of the ballot box
(D) Burning of election materials

41. The following stages are involved in organizing free and fair election Except
(A) Delimitation of constituencies
(B) Registration of voters
(C) Registration of underage voters
(D) revision of voters card

42. All these are forms of electoral malpractice except;
(A) Stealing of election materials
(B) Rigging of election
(C) Mutilation of election results
(D) Announcing the election results

43. Electoral malpractice leads to;
(A) Loss of lives
(B) Apathy
(C) Corrupt leadership
(D) All of the above

44. Which one of these countries practices second ballot system?
(A) Ghana
(B) Liberia
(C) France
(D) All of the above

45. The purpose of a free and fair election is to;
(A) allow people to participate in choosing their leaders
(B) Provide basic amenities for the electorate
(C) declare election results
(D) Buy the electorates' vote

46. Free and Fair election can be achieved through;
(A.) Secret balloting
(B). Rigging
(C.) Plebiscite
(D) Violence

47. The shortfall of an electoral college is that;
(A) Wrong candidate nay be chosen
(B) People's right of choice is denied
(C) it encourages bribery and corruption 
(D) All of the above

48. Primary election is an election held by;
(A) President
(B) Governor
(C) Political Parties
(D) INEC

49. The process where the electorates vote for the representatives who in turn vote on their behalf is called;
(A) a rigged election
(B) an unfair election
(C) an indirect election
(D) An unpopular election

50. An election in which all the electorates appoint their representative is known as;
(A) Free and fair Election
(B) Direct election
(C) By-election
(D) Indirect Election 


\section{Appendix B}

\section{Government Interest Inventory (GII)}

\section{Section A: Personal data of student}

$\begin{array}{lll}\text { Sex: } & \text { Male [ ] } & \text { Female [ ] } \\ \text { Age: } & \end{array}$

Class:

School:

\section{Section B: GII Items}

\section{Instruction:}

This inventory is designed to help you indicate voter education related contents that interest you and which you would like to actively participate in. Indicate the extent you would want to participate in them by ticking $(\sqrt{ })$ against the options:

SA - If you would very much like to engage in the activity or take interest in the aspect

A - If you would very like to engage in the activity or take interest in the aspect

D- If you would dislike to engage in the activity or take interest in the activity or take interest in the aspect.

SD - If you would very much dislike to engage in the activity or take interest in the aspect.

Please complete the following:

\begin{tabular}{|c|c|c|c|c|c|}
\hline $\mathbf{S} / \mathbf{N}$ & Item Statement & SA & $\mathbf{A}$ & D & SD \\
\hline 1. & I am willing to read Government textbooks at my free time. & & & & \\
\hline 2. & I prefer to buy Government textbooks with my extra money. & & & & \\
\hline 3. & I participate actively in Government classes. & & & & \\
\hline 4. & I love to learn Government as a subject. & & & & \\
\hline 5. & I do not like to miss Government class. & & & & \\
\hline 6 & I enjoy discussing topics in Government with my fellow students. & & & & \\
\hline 7. & I am willing to study Government beyond school certificate level. & & & & \\
\hline 8. & I would encourage my mates and friends to take interest in Government subject. & & & & \\
\hline 9. & Any money spent on Government books is not a waste. & & & & \\
\hline 10. & Government subject brings progress in the nation. & & & & \\
\hline 11. & I do not like going to class when Government lesson is going on. & & & & \\
\hline 12. & I am proud to be identified as a student of Government subject. & & & & \\
\hline 13. & I like to move out of the class when the teacher is teaching Government. & & & & \\
\hline 14 & I do not like attempting questions asked in Government. & & & & \\
\hline 15. & I would readily pay for extra lessons on Government. & & & & \\
\hline 16. & I do not accept take home assignments in Government. & & & & \\
\hline 17. & I hate to help produce materials for teaching Government. & & & & \\
\hline 18. & I feel happy in Government class. & & & & \\
\hline 19. & I am not willing to contribute books for learning Government. & & & & \\
\hline 20. & I enjoy using my knowledge of Government to solve problems at home. & & & & \\
\hline 21 & I am familiar with the word election & & & & \\
\hline
\end{tabular}




\begin{tabular}{|l|l|l|l|l|}
\hline 22 & $\begin{array}{l}\text { I am aware that the voting age in Nigeria is from 1 } \\
8 \text { years }\end{array}$ & & & \\
\hline 23 & I am taught that properly conducted election brings peace & & & \\
\hline 24 & I learnt that improperly conducted election leads to political violence & & & \\
\hline 25 & I am excited learning about political issues in the class & & & \\
\hline 26 & I learnt that voting by all qualified citizens helps in choosing acceptable leaders. & & & \\
\hline 27 & I do not have interest when electoral issues are discussed & & & \\
\hline 28 & I learnt that voter apathy do not promote democracy & & & \\
\hline 29 & I am willing to vote when I am 18 years & & & \\
\hline 30 & I would encourage my friends to take interest in voting process & & & \\
\hline
\end{tabular}

\section{Copyrights}

Copyright for this article is retained by the author(s), with first publication rights granted to the journal.

This is an open-access article distributed under the terms and conditions of the Creative Commons Attribution license (http://creativecommons.org/licenses/by/4.0/). 